\title{
Solidariedade internacional
}

\section{Equipe brasileira atende vítimas do terremoto no Haiti}

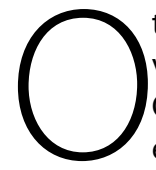

terremoto ocorrido no Haiti em 12 de janeiro de 2010 vitimou 240 mil e deixou milhares de mutilados. O Governo brasileiro iniciou ajuda humanitária, envolvendo ministérios civis e militares. O Grupo Hospitalar Conceição (GHC) de Porto Alegre, formado pelos Hospitais Nossa Senhora da Conceição, Criança Conceição, Cristo Redentor, Fêmina e 12 Unidades de Saúde Comunitária, manifestou interesse em assistir a saúde à essa população. Em 26 de janeiro os profissionais do $\mathrm{GHC}$, seis enfermeiros e quatro médicos, partiram ao Rio de Janeiro para encontro com Dr. Oscar Berro, Diretor do Departamento de Gestão Hospitalar/Rio de Janeiro/Ministério da Saúde e representante da Diretoria do GHC, Dr. Neio Lúcio. A coordenação dos profissionais civis, nesta missão é da Enfermeira Fátima Ali; e em 27/01, os profissionais civis unem-se aos militares da Marinha Brasileira.

Em 28/01 a Missão Binacional Brasil-Itália formada por 11 civis brasileiros, junta-se ao grupo do GHC um profissional médico do Ceará, 93 militares da Marinha, profissionais de saúde e Departamento Aéreo, além da tripulação de 1.300 militares italianos do porta-aviões, zarparam para travessia do Atlântico e em 01 de fevereiro, atracou em Porto Calceda (República Dominicana).

Desembarcaram jipes, caminhões do exército, containers com armas, água, comida e medicamentos.

Iniciava a Operação Guindaste Branco.

O navio possuía área para tratamento hospitalar com ambulatório, odontologia, farmácia, laboratórios, RX, ecografia, tomografia, centro de materiais e esterilização, salas cirúrgicas, gesso e queimados, 24 leitos de internação, oito para terapia intensiva e câmara hiperbárica.

Apesar do desejo de sair para atender a população desesperada, o grupo permaneceu a bordo e recebeu o primeiro paciente em 02/02, um haitiano com amputação do MID.

\section{Atendimento humanizado}

Respaldados pelo SUS - saúde é direito inerente a todo ser humano, o grupo defendia a urgência em desembarcar para expandir o tratamento às vítimas. Os comandantes de saúde militar sobrevoaram Porto Príncipe para detectar necessidades de socorro e no dia 3/02, dois enfermeiros civil e militar deixaram o navio indo para o Hospital da Fundação Rava. Ao lado de Kenol, outros pacientes em estado grave eram atendidos no navio.

O trabalho foi revezado entre profissionais civis e militares. A Assistência de Enfermagem aos oito leitos de cuidados intensivos ficou sob a responsabilidade da enfermagem brasileira.

No carnaval com a ideia do "Carnavou" nasceu a possibilidade de atendimento em terra. A partir de 15/02 formaram-se três escalas de atendimento, com abertura do Site du Soley, imensa favela próxima ao porto. Uma lancha partia levando o grupo que atendia em barracas até 50 pessoas/dia. Dois dias após

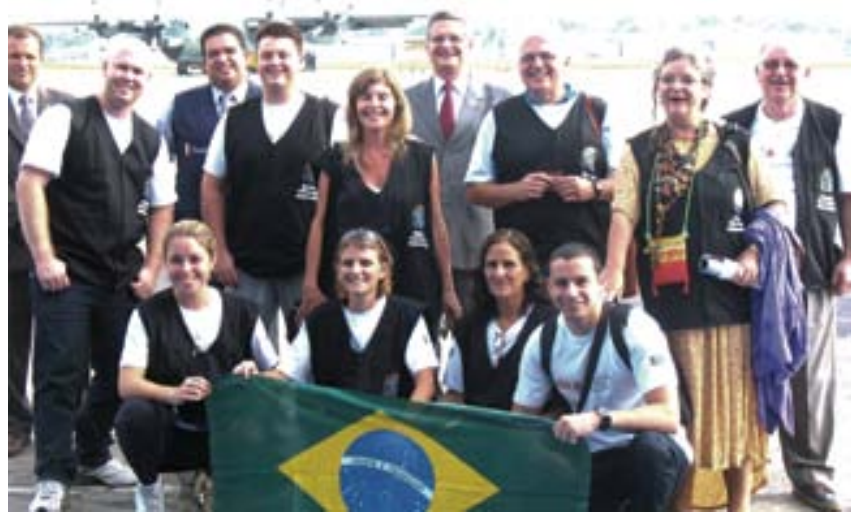

Participaram da missão Haiti os profissionais de enfermagem: Cléber Verona, Eloísa Nonnemacher, Fátima Ali, Gabriel Messerschimidt, Sue Helen Barreto Marques e Thiago Cunha dos Santos; e os de medicina: Lúcia Helena de Albuquerque Souza, Luiz Mário Bretanha de Moraes, Márcio Carlos Seelig e Maria da Graça Falkembachnen.

inicia o atendimento em Saint Marc, cerca de 80 quilômetros de Porto Príncipe, por vôos diários de helicópteros. Cerca de 240 habitantes recebiam cuidados médicos, em um trabalho realizado em parceria com profissionais da Defesa Civil Italiana. O Hospital Cavour desempenhava o papel de retaguarda, ainda que não dispusesse dos recursos necessários. A falta de infraestrutura básica foi suprida pela criatividade e improvisação e o espírito de equipe ajudou a salvar vidas, como a do jovem baleado com lesão arterial que sobreviveu graças à cirurgia realizada por uma equipe multiprofissional e multinacional.

\section{Missão cumprida}

O Haiti marcou cada membro da equipe, que não esqueceria que a maioria da população tem hérnia umbilical, jovens portadores de úlceras venosas e cataratas, desnutrição. Mesmo dispondo de parcos recursos, realizaram importantes atendimentos, constatando existência de doenças crônicodegenerativas; gestantes sem acompanhamento de prénatal; proliferação de doenças parasitárias e infecciosas; entre muitas outras enfermidades endêmicas.

Em meio à tragédia, tornava-se claro que o objetivo do grupo atingira sua meta: atuar como socorro de emergência. Em 18/02 ocorreu nova conferência com a participação dos comandantes militares da Missão Cavour que constatou que os atendimentos não se restringiam às vítimas do terremoto.

Em 23/02, o grupo recebe a visita do representante do MS do Brasil, Dr. Carlos Felipe Almeida D'Oliveira. O embarque para retorno dos profissionais civis ocorreu no aeroporto de Porto Príncipe, dia 27/02, em um Boeing da Força Aérea Brasileira. Após 32 dias, terminava a participação civil da Missão Cavour, mas não da Missão Haiti, que engloba o estabelecimento de programas em comunidades, além do intercâmbio para formação de profissionais de saúde.

Agradecimentos

Aos militares brasileiros e italianos.

Porto Alegre, março de 2010. 